\title{
Is a Long-term Business Relationship an Implied Contract? Two views of a Relationship "Disengagement"
}

\author{
Debbie Harrison \\ Lancaster University Management School, \\ Lancaster. \\ Telephone 0152465201 ext. 94833, \\ E-mail:D.J.Harrison@lancaster.ac.uk
}

In this paper an approach to the study of relationship dissolution as a consequence of midrange network change is presented. The key idea is to explain two divergent views of the possibility for legal redress following dyadic relationship disengagement: long term relationship as implied contract, and contract-in-law. An empirical example of an exclusive customer-supplier relationship is presented. The paper concludes by discussing the features of the Marks and Spencer case for the relational contracting, transaction cost economics, and industrial network literatures.

\section{I Introduction}

"As more and more exchanges tend toward the longer-term, contract law's effectiveness in governing these relationships can be expected to diminish as exchange parties favor more theoretically consistent and amenable modes of governance" (Gundlach and Achrol (1993:152)).

Industrial network literature has considered the theme of network change in a variety of different ways. These range from micro studies of focal actors' responses to change from outside its boundaries (Easton and Lundgren (1992)) to the description of the evolution patterns of networks using a variety of generic patterns of change (Hakansson (1992); Hakansson and Henders (1995)). Some researchers have provided micro, empirical analysis of the dynamics of discontinuous or radical change within industrial networks, using change events from both within (e.g. Uusitalo and Malinen (1999); Havila and Salmi (1999)) and external to (e.g. Harrison (1999)) a network.

Hakansson and Snehota suggest that "while exogenous events and entrepreneurial action can cause change in relationships and thus in business networks, the major source of change is the interaction within relationships" (1995:271). This paper will focus upon one impact of a 'middle ground', mid range event between exogenous 'shocks' and day-to-day changes: the planned change of supplier relationships within a network. A key customer might wish to manage their supplier portfolio by reducing the number of supplier relationships.

This is what Marks and Spencer (M\&S), the UK's largest retailer, began to do in 1999 vis a vis textiles suppliers. M\&S plan to make cost savings of $£ 400 \mathrm{~m}$ over a four-year period. One major area for savings was to switch some of the UK supply-base overseas. The outcome was to have several dissolved relationships with non-retained suppliers, and changed relationships with continuing suppliers. 
One of the disengaged suppliers, William Baird, is now suing M\&S for $£ 53.6 \mathrm{~m}$ " ... for breach of contract after it was dumped after a 30-year relationship" ${ }^{87}$. The legal argument of William Baird is that a long-term relationship is akin to an implied contract between actors, even in the absence of a formal contract. Hence, the relationship exists in legal terms, and affords legal redress. Their customer considers that the same relationship had no basis in law, because there was not a formal contract, and that there are no further obligations toward an ex-supplier. An M\&S spokesperson has stated that "we will fight any court action and that our legal advisors have said Baird's case has "no merit" " 88 . The forthcoming legal case is likely to be debated upon the period of notice given by M\&S to their former supplier. A full period of notice might have permitted William Baird to convert asset specific investments to new business with other clothing retailers.

The relationship between the actors was long-term, exclusive, and involved heavy investment in plant, machinery and human assets. A non-legal way of operating was the norm, as $M \& S$ do not have formal contracts with any of their suppliers. The nature of the ongoing relationship between the actors did not suggest that legal redress would be necessary. There are few studies of relationship dissolution in IMP (for exceptions see, for example, Tahtinen (1999)). This paper does not attempt to add to our current understanding of the process of relationship dissolution, but instead to explain two highly divergent viewpoints of the possibility for legal redress following the termination of a long-term relationship.

"The governance of interfirm transactions has been described as a contracting problem" (Gundlach and Achrol (1993:142)). Yet formal contracts must be incomplete however much planning takes place because of unforeseeability and inappropriate adaptations by the parties (Williamson (1983)). Further, not all contracts between industrial actors can be formal, written, and complete as in the classical contract law view: "...long term contracts often amount to little more than framework agreements which depend on-going discussions and negotiations to assure mutually acceptable adaptations to unanticipated events" (Lorenz (1999)).

This raises an interesting question as to the forms that business to business contracts can take, and what features are necessary for their negotiation and effectiveness, e.g. trust (Lyons and Mehta (1997)). Non-market enforcement can be achieved by "self-enforcement on the basis of repeated exchange; third party enforcement, using legal sanctions, and the internalisation of production through the firm" (Deakin, Lane, and Wilkinson (1994:334). Hybrid forms of governance can invoke mechanisms of a written contract, or implied contract based on legal doctrines (e.g. fairness) and / or relational norms.

Governance structures, and their respective governance mechanisms, can be broadly considered in three main literatures: transaction cost economics, relational contracting and industrial networks. This paper will briefly outline each of these three literatures in turn before applying each to a case study of Marks and Spencer and William Baird.

\section{2. / Literature review}

\section{1/ Transaction cost economics}

Transaction cost economics (TCE) is a theory of exchange. TCE considers the most appropriate governance structure for conducting an economic transaction in the most efficient

\footnotetext{
${ }^{87}$ M\&S sales plummet, 12/1/00, www.news.bbc.co.uk

${ }^{88} \mathrm{M} \& \mathrm{~S}$ sued by supplier, 11/1/00, www.news.bbc.co.uk
} 
manner depending upon a combination of the nature of a given transaction, the resulting asset dependencies, and various fixed human behavioural characteristics. Without the risk of opportunism and bounded rationality, there would be no need to safeguard assets. Transaction costs are "...the "costs of running the system" and include such ex ante costs as drafting and negotiating contracts and such ex post contracts as monitoring and enforcing agreements" (Rindfleisch and Heide (1997:31)). A situation whereby there are low transaction costs will result in a market mode of governance, and high transaction costs will favour a hierarchy or internal mode of governance. "Economising on transaction costs essentially reduces to economising on bounded rationality while simultaneously safeguarding the transactions in question against the hazards of opportunism" (Williamson (1979:246)).

Exchanges can be made within several governance structures. Exchanges can be made in the marketplace, within the hierarchy (the organisation), or within hybrid modes (trilateral and bilateral) of production (though Williamson did not discuss these modes in his earlier work). "The hybrid form of organisation is not a loose amalgam of market and hierarchy, but possesses its own disciplined rationale" (1991:294). The two hybrid modes can be distinguished by their underlying control mechanisms. Trilateral hybrid governance mechanisms are those of independent actors and formal contracts (Rindfleisch and Heide (1997). Bilateral hybrid governance mechanisms include relational / social norms and joint investments.

Certain structures or modes of production for commercial exchanges are more suitable in particular circumstances or contexts. In Williamson's 1979 model, the parameters are related both to human behaviour (bounded rationality, opportunism, risk neutrality) and features of transactions or exchanges (asset specificity, transaction frequency, uncertainty). There are a variety of types of asset specificity: site, physical asset, human asset, brand name capital, dedicated assets, and temporal $(1979,1983,1991)$. Safeguarding these various assets is critical because of the dependencies created between the two transacting parties. The more specific the assets, the higher are the transaction costs because of the need to protect against "contracting hazards" (1991:282). Dedicated assets are "...discrete investments in general purpose plant that are made at the behest of a particular customer" (1991:281). One way of safeguarding very specific investments is through the use of "hostages", or posting bonds, making joint investments, the customer investing in (at least some of) the required plant and machinery, etc. by both parties. The other governance mechanism for the hybrid is through resource to third parties (Williamson (1983)).

Williamson then related the three governance structures to the most appropriate type of contract law. "In terms of Macneil's three-way classification of contract, classical contracting presumably applies to all standardised transactions (whatever the frequency), relational contracting develops for transactions of a recurring and non-standardised kind, and neo-classical contracting is needed for occasional, non-standardised transactions" (1979:248). This early model was extended through the later thesis whereby governance costs are a function of asset specificity and particular external / institutional contexts (including types of contract law) (Williamson (1991)). A change in the context leads to changes the comparative transaction costs of alternative 'generic' modes of governance. The hybrid modes are supported by incomplete long-term contracts: "Because there is bilateral dependency, however, long-term contracts are supported by added contractual safeguards and administrative apparatus (information disclosure, dispute-settlement machinery)" (1991:280).

In their recent review paper, Rindfleisch and Heide (1997) present a helpful synthesis of the use of TCE in marketing. Their classification of studies into four main branches illustrates an 
implicit bias towards assessing hybrid modes of governance: vertical integration, vertical interorganisational relationships; horizontal interorganisational relationships; and tests of TCE's assumptions (p34). There has been some, if limited, empirical support for TCE (e.g. see Maher (1997) and Murphy (1999)). Other well-discussed limitations of transaction cost economics include that the unit of analysis is the transaction and not the relationship (Williamson (1983), Johanson and Mattsson (1987), Grabher (1993)). As Rindfleisch and Heide state, a cross sectional view "...ignores the temporal nature of interorganisational relationships" (1997:48). Expectations of the future continuity of a relationship are an essential component for building long-term relationships (Anderson and Weitz (1989), Grabher (1993), Griesinger (1990), Kumar, Scheer, and Steenkamp (1995), Rindfleisch and Heide (1997)). Other researchers also criticise TCE for missing elements such as innovation and learning (Lundvall). Further, there are few dynamic models of governance modes (see Noorderhaven (1995)). Lastly, Buckley and Chapman (1997) argue that managerial perceptions of transaction costs are of relevance, rather than abstract analyses.

\section{2/ Relational contracting}

Simplistically, there are two main views as to whether the use of long term contracts in business to business relationships are as prevalent as Williamson suggests. Contracts have been found to be important in long-term relationships (Joskow (1988, 1990), (Leffler and Rucker (1991), Gundlach and Achrol (1993)). According to Joskow, the more specific to a particular relationship are investments, the longer the contracts that are negotiated are. Further, businesses operating in environments characterised by high uncertainty were found to use contracts replicating hierarchies in attempting to reduce uncertainty (Gundlach and Achrol (1993)).

However, in a seminal reference, Macaulay (1963) found that business does not resort to the use of formal contract law as often as TCE would assume. Transactions or relationships are not planned in full, with the use of legal sanctions to enforce contracts / settle disputes. Murphy (1999) found little emphasis on legal form, especially in longer-term relationships. Contracts can be self-enforced through features such as trust, relationship continuity, social norms, custom and practice, 'unwritten laws', and repeat trading (Deakin, Lane, and Wilkinson (1994)). In other words, governance mechanisms for hybrid structures are a combination of contract law and self-enforcement mechanisms, e.g. norms and custom and practice (Gundlach and Achrol (1993), Burchell and Wilkinson (1997)).

Self-enforcement in business relationships, such as norms, industry customs, reputation, or an assumption of continuity, can be alternatives to contractual practices (Macaulay (1963), Macneil (1980)). Indeed, business contracts can take many forms, be they written, formal, or verbal or explicit or implicit; each can be legally binding (Lorenz (1999), Lyons and Mehta (1997), Macaulay (1963)). There is also confusion as to what types of transfer can be considered to be a contractual agreement by some actors. Procedural rules, such as the use of the order form, were in place in Lorenz's (1999) study, because of market uncertainty. Very similar to this is Macaulay's (1963) standardised planning, whereby standard documentation, such as order forms, are passed between organisations, with standard terms included.

Relational contract is a different view from transaction cost economics as an alternative to the inappropriateness of classical contract law. In the former, contracts are considered to be incomplete, with legal structures in place for the settlement of disputes. In relational contracting, an incomplete contract in a business to business relationship is supplemented by relational contract norms, or social norms, such as role integrity and harmonisation of 
relational conflict. Cannon, Achrol, and Gundlach (2000) refer to this as plural form governance. These norms are differ in emphasis from the norms that underlie what Macneil refers to as 'discrete exchanges', and hence, distinguish types of exchange.

Several empirical studies of business relationships have 'tested' a number of Macneil's contractual norms (e.g. Dwyer, Schurr, and Oh (1987)). Boyle, Dwyer, Robicheaux, and Simpson (1992) used the norms of solidarity, mutuality, and flexibility in order to "measure" relationalism in their study of influence strategies. Similar norms were found to be important by Heide and John (1992) for manufacturer-supplier relationships. I.e. more to it than simply bounded rationality, etc. from TCE. Das and Teng (1998) discussed the role of confidence between business partners as a way of managing the risk of opportunistic behaviour. A client's perception of relationship strength is affected by the three relational norms of solidarity, flexibility, and communication (Paulin, Perrien, and Ferguson (1997)).

Other work has compared how the interrelationship of trust and contractual environment (laws, standards, and customs) in different countries influences contract types in interorganisational relationships (Choi (1994), Burchell and Wilkinson (1997), Deakin, Lane, and Wilkinson (1994), Arrighetti, Bachmann and Deakin (1997)). "Detailed formal contracts were usual among the German and Italian firms but were less common amongst the British firms" (Burchell and Wilkinson (1997:234), also Arrighetti, Bachmann and Deakin (1997)).

Some authors have studied the coexistence between norms and the formal legal system. Charny (1996) considers the contexts whereby it would be difficult for the court to enforce norms. "...The rules that parties follow when the play among themselves are not those that a court should attempt to apply" (1996:1854). Some studies have assessed relational contracting using industry norms outside of the prevailing legal environment, though with one fascinating point of difference. In the situation of an underdeveloped legal framework, trading clubs were found because the identity of trading partners is crucial when there is no institutional framework for well worked contract to be in place. Landa (1994) found that the anonymity assumption of classical contract law is inappropriate. A system of "private governance" or "private law" can also take place within the context of a well-established legal system (Bernstein (1992)). In her study diamond trading clubs operate within rules established extra-legally, and where the system of rule enforcement, and redress, is also extra-legal.

\section{3/ Industrial networks}

Industrial activities can be governed via a particular type of hybrid, bilateral agreement: the interaction between actors in long-term exchange relationships embedded with industrial networks (Hakansson and Johanson (1993), (Mattsson (1987), Hakansson and Johanson (1988)). Other authors consider networks to be an efficient alternative to the market when most actors are co-operative in their behaviour (Kali (1999)).

Johanson and Mattsson (1987) make a comparison between the industrial network approach and transaction cost economics using dimensions such as theoretical foundations, problem orientation, basic concepts, and nature of relationships. IA and IMP have its own ontology vis a vis the nature of business relationships. This is based upon mutuality, exchange, adaptation (logistics, technical, administratively, knowledge), with adaptation type related to the type of interaction between the parties. There is less emphasis on formal contract law and an interest in the dynamics of industrial systems rather than governance choices. A mutual orientation develops over time and is "...manifested in a common language regarding 
technical matters, contracting rules, and standardisation of processes, products, and routines" (ibid. p39). Safeguards are "neglected" because of differences concerning the risk of opportunism and bounded rationality (Noorderhaven (1995)). Further, at least some asset specificity would be expected, because of resource dependencies between actors in a net.

The IMP approach views industrial markets as "...networks of relationships between firms" (Mattsson (1987:249)). In the industrial network approach the key theme is connectedness. The basis of relationships is the exchange of resources and the interrelationships between activity structures (Hakansson and Johanson (1988), (Hakansson and Snehota (1995)). Over time resource exchanges between actors lead to relationships "...that link the resources and activities with one party with those of another" (Hakansson and Snehota (1989)). Cooperative relationships between actors are the norm and have been found to be most common from empirical studies (e.g. Hakansson and Johanson (1988); Hakansson (1989); Hakansson and Henders (1992); Axelsson (1992); Easton and Araujo (1989)). Relationships are built up over time, involve resource commitments, and are long term, rather than based on short-term contractual agreements (e.g. Johanson and Mattsson (1985); Hakansson and Snehota (1989)).

Indeed, both the present and future performance of an actor is influenced by their interaction relationships as "...the industrial network is a product of its history" (Hakansson and Johanson (1988:371)). The current relationship acts as the stage for subsequent interactions (Ford, McDowell, and Tomkins (1996:38)), and is based on features such as trust rather than formal contractual elements. The nature of an interaction between actors can vary by a number of characteristics; frequency, regularity, and the extent of explicitness. The basis of the interaction between actors is that of norms, "...either...prescribed by some authority or... agreed upon by different actors" (Hakansson and Johanson (1993:44)). Exchange results in interdependencies between actors, or rather resource dependencies. In any network there is a power structure of relationships based on resource dependencies. The network position of an actor in part depends upon the resources controlled by that actor, which are desirable to other actors (Kutschker (1985); Hakansson and Johanson (1988)).

\section{3. / Case Study}

A case study currently based upon secondary data and telephone interviews shall be used to provide a background to $M \& S$ restructuring their clothing supply-base. The position of Marks and Spencer was as a central and exclusive customer. There were seven main clothing suppliers within the focal net, some of whom have been retained, and others that have been dropped. The main trends are that UK production is now concentrated with M\&S's three largest suppliers, Dewhirst (women's clothing), Courtaulds Textiles (women's and men's leisurewear), and Coats Viyella. Cooper and Roe have been retained to make some lines but have lost others. The three main disengaged suppliers are William Baird, Richard Roberts (knitwear), and Daks Simpson (men's clothes). The retained suppliers are being encouraged to shift the re-distributed production overseas. Overseas suppliers (no details available) that M\&S are to have "increased dealings" with are located in North Africa, Morocco, Germany, France, and the Far East.

\section{Changing the clothing supply base}

$\mathrm{M} \& \mathrm{~S}$ is the UK's largest clothing retailer. The company holds $40 \%$ of the UK underwear market, sells $50 \%$ of ready-made meals sold in the UK, and holds $19 \%$ of the UK women's 
clothing market ${ }^{89}$. They have 700 stores, 71,000 employees, and a market value of $£ 8.5 \mathrm{bn}$. M\&S are currently suffering poor trading performance: 1999 profits were $£ 545 \mathrm{~m}$, compared to $£ 1.16$ bn in $1998^{90}$. The fall in profits has been blamed on a combination of poor trading in overseas operations, a drop in UK sales and the cost of selling unsold stock at a discount, and sourcing from their UK supplier base ${ }^{91}$. This is the first fall in profits for 30 years ${ }^{92}$.

M\&S are currently in the process of relocating and restructuring their supply base ${ }^{93}$. The company has stated a need to move to a position whereby $30 \%$ of clothing items will be sourced from the UK, and 70\% from overseas by 2002. At present the balance is approximately $50 / 50{ }^{94}$. Moving the supply base overseas is expected to result in lower production costs, economies of scale, and the speeding up of deliveries ${ }^{95}$. There is also a small matter of achieving $£ 400$ million in planned cost savings by 2002 .

M\&S plan to establish a "global supply chain with manufacturing hubs" in countries such as Portugal, Morocco, and Sri Lanka. The aim is to become more customer-demand driven ${ }^{96}$ via this "key strategic step" for the company" 97 . Suppliers are expected to deal with the M\&S price pressure by switching production overseas. The impact upon the UK clothing industry is estimated to be to put 10,000 jobs at risk ${ }^{98}$.

\section{Impact upon UK suppliers 1: Job Losses}

Dewhirst is planning to cut 1,000 jobs and close 4 factories in the UK. 10 factories in the UK will remain, with other production being moved overseas to Morocco, Indonesia, and Malaysia. $90 \%$ of Dewhirst's business is for one customer: M\&S ${ }^{99}$. This does not appear to be unusual, and the GMB union is on record stating that it is unhappy about M\&S "...stipulating that suppliers work exclusively for them" ${ }^{100}$. Richard Roberts, a supplier of knitwear to M\&S, was de-listed on the 2/11/99 (along with Daks Simpson). This is another organisation with which M\&S had a 30-year relationship. 900 jobs are now at risk at Richard Roberts (with 800 at Daks), not least because $70 \%$ of the turnover of the company was for one customer... ${ }^{101}$. A week later, it was announced that clothing manufacturer Martin International's Cooper and Roe division disengaged from M\&S, stopping supply of knitwear past the spring / summer 2000 season. The company reported that 700 jobs are now at risk.

\section{Impact upon UK suppliers 2: Legal Action}

One of the disengaged suppliers, William Baird (supplier of lingerie, women's coats, and men's clothes, or 7\% of the total clothing stock ${ }^{102}$ ) was also informed during October 1999 of the "decision to disengage from them following the completion of contracts for spring /

\footnotetext{
89 King Richard: A tragedy in three acts, Management Today, April 1999, M. Gwyther, pp 78-85.

90 M\&S sales plummet, 12/1/00, www.news.bbc.co.uk

91 Buyers take blame for M\&S losses, Supply Management, 27/5/99, E. Bellamy

92 Business: Black marks, The Economist, 6/11/99, Anonymous

93 www.marks-and-spencer.co.uk

${ }^{94}$ Marks and Spencer clarifies the position on buying from the UK, M\&S press release, 29/11/99, www.marksand-spencer.co.uk

${ }^{95}$ Marks and Spencer Announces Fundamental Changes to Buying Process, M\&S press release, 2/11/99, www.marks-and-spencer.co.uk

${ }^{96} \mathrm{M} \& \mathrm{~S}$ sales plummet, 12/1/00, www.news.bbc.co.uk

${ }^{97}$ M\&S losses due to overseas policy, Supply Management, 21/10/99, E. Bellamy

${ }^{98}$ Marks and Spencer dramatically shifts supply base, Bobbin, February 2000, N. Tait

${ }^{99}$ M\&S cuts take toll of Dewhirst, M. Selva, Daily Telegraph, 14/1/00, p31.

${ }^{100}$ M\&S sued by supplier, 11/1/00, www.news.bbc.co.uk

${ }^{101}$ M\&S axes another supplier, 6/11/99, www.news.bbc.co.uk

102 Axed clothing supplies sues M\&S, Supply Management, 27/1/00, D. Arminas
} 
summer $2000 \% 103$. $40 \%$ or $£ 200$ million of the overall business of William Baird was in manufacturing clothes for M\&S ${ }^{104}$. In fact, the whole of one division, Baird Clothing, had only one customer.

One month later, William Baird announced its intention to sue M\&S for $£ 53.6 \mathrm{~m}$. $£ 53.6 \mathrm{~m}$ represents the "...difference between the company receiving three years' notice and the summary termination which it received on 22 October" ${ }^{105}$. The amount is to cover $£ 33 \mathrm{~m}$ of redundancy payments for 4,500 staff by the end of April 2000, and other costs regarding closing factories and for asset write-downs ${ }^{106}$ used to fulfil orders. One central rationale in the legal claim is that William Baird considers they were entitled to a three-year notice period. David Suddens, the C.E.O., states: "We regret that M\&S has been unwilling to make proposals which properly reflect the notice that ought to have been given on the unilateral termination of a 30 -year business relationship” “ 107 .

The relationship between William Baird and M\&S has been described as being a "very different customer-supplier relationship from the 'normal' relationship because it was more like a partnership than invoice or specification based" ${ }^{108}$. However, there was no written contract between the two actors; instead transactions were order-driven. In fact, none of M\&S's suppliers have written contracts ${ }^{109}$. The basis of the William Baird claim is that a verbal contract was in place, coupled with the existence of a long-term relationship. "M\&S has always boasted about the special relationship it had with its suppliers, but David Suddens claims M\&S “encouraged" Baird to halt production of other retailers' own-label garments, and even told the company where it must buy all its fabric" 110 .

Hence, the basis of the High Court action is that the lack of a written contract between the two organisations is irrelevant. A long-term relationship is akin to an implied contract, and hence, is legally enforceable. William Baird is therefore suing M\&S "...for breach of contract after it was dumped after a 30-year relationship" 111. "We are extremely disappointed that a longstanding relationship, based on mutual trust, has been terminated unilaterally “ ، 112 .

The position of M\&S, however, is that the organisation intends to "...fight any court action and that its legal advisors had said Baird's case had "no merit" " ${ }^{113}$. M\&S do not support these claims contained within the legal documents submitted by William Baird. Instead, "our legal advisors tell us that there is not a legal case to answer " 114 .

\footnotetext{
${ }^{103}$ Marks and Spencer clarifies the position on buying from the UK, M\&S press release, 29/11/99, www.marksand-spencer.co.uk

104 Axed clothing supplies sues M\&S, Supply Management, 27/1/00, D. Arminas

${ }^{105}$ M\&S sued by supplier, 11/1/00, www.news.bbc.co.uk

${ }^{106}$ Baird launches $£ 53 \mathrm{~m}$ claim against M\&S, J. Finch, 12/1/00, www.newsunlimited.co.uk/business

107 Ibid.

${ }^{108}$ Telephone interview with William Baird PR agent, 13/1/00

${ }^{109}$ Baird launches $£ 53 \mathrm{~m}$ claim against M\&S, J. Finch, 12/1/00, www.newsunlimited.co.uk/business

${ }^{110}$ Ibid.

${ }^{111}$ M\&S sales plummet, 12/1/00, www.news.bbc.co.uk

${ }^{112}$ David Suddens, CE of William Baird, quoted in M\&S down-turn threatens 4,300 UK jobs, 22/10/99, www.news.bbc.co.uk

113 Ibid.

114 Ibid.
} 


\section{4. / Case Explanation}

The case study illustrates the two divergent viewpoints of the dissolved customer-supplier relationship. The central question for the paper is whether or not there was a contract between M\&S and William Baird given the features of the relationship and the nature of the exchanges between the actors.

A relationship that is based upon multiple recurring and non-standard transactions is clearly a bilateral hybrid mode of governance. This mode of governance should operate matched to relational contracting as the most appropriate type of contract law (Williamson (1991)). The hybrid mode of governance has a variety of possible governance mechanisms dependent, not least, upon the type of hybrid in question. Williamson would expect a hybrid to be regulated through the use of an incomplete long-term contract, with hostages or redress to third parties in place.

Simplistically, M\&S appear to have taken a view of the relationship as a trilateral hybrid mode, with the parties as independent, formal contracts, and recourse to a third party for redress. Because a formal contract was not in place, redress is uncertain in their view. This position is what Macneil would term contract-in-law, based upon transaction cost economics and neo-classical law. By contrast, William Baird seems to consider the dissolved relationship as a bilateral hybrid, with governance mechanisms based on relational norms and joint investments. This is more of a contract-in-fact or implied contract standpoint.

\section{1 / Contract-in-law - Marks and Spencer}

Long-term contracts when large investments are made would be expected in hybrid modes of governance from a legal-economic view (Maher (1997:164)). "Instances in which contracting parties actively seek to avoid placing their agreements in some kind of legal form are rare" (Burchell and Wilkinson (1997:220), citing Arrighetti, Bachmann, and Deakin (1997)). Indeed, social or relational norms are generally expected in addition to some kind of formal agreement, however incomplete.

The formation and maintenance of the business relationships between $M \& S$ and their supplier involved not having written contracts. In addition, the customer-supplier relationship is exclusive and long-term. Yet, $M \& S$ has taken a transaction cost / neo-classical law perspective on their dissolved relationship with William Baird. Their position views that an incomplete contract must be formal, written, and explicit. Legal redress through third parties or the posting of hostages is the two main relevant contractual practices. Hence, such a contract must be in place for legal redress to be possible.

The transactions within the relationship were order based, timed at particular points of the year based on future seasons of clothing. The use of orders within business relationships can be considered to be short-term or one-off transaction instruments (Burchell and Williamson (1997)), and not synonymous with contract. Yet the two actors had many interdependencies as a result of their long-term relationship.

In addition, $M \& S$ did not post hostages, or make credible commitments, although there was obviously an investment in human assets. There were no safeguards for suppliers apart from continuing and regular orders. (This would be expected from the IMP literature, but by taking a different ontological position about relationships). The actor was a very central and extremely powerful customer in the net, with several highly dependent suppliers. M\&S could 
use that power to influence how garments were manufactured, where cloth was sourced from, and the nature of supplier adaptations.

\section{2 / Contract-in-fact - William Baird}

Another form of incomplete contract is informal, verbal, and relational. Contractual practices are then self-enforcement of a relationship, based on features such as trust, relationship continuity, norms, custom and practice, and repeat trading. According to William Baird an implied contract was in place between the two actors, based on the existence of a long-term relationship and a verbal agreement, and hence there is scope for legal redress.

One central issue is based on Macaulay's finding that the use of formal contract law is not as prevalent in business transactions as some would expect. However, there is a difference between incomplete and non-existent contracts when one actor wishes to terminate a relationship.

A contract can exist between actors even if it is formally recorded in writing because there are multiple forms of business contracts. Studies report that not all long-term relationships are governed by written contracts (e.g. Hakansson (1989), Maher (1997)). Confusion might exist over whether orders or standard documentation represent or are synonymous with a contract (Macaulay (1963)). The relationship in question was order-driven at several points of the year for seasonal clothing. There was a pattern of repeat trading and an expectation of continuity of orders, at least on the part of the supplier. Empirical studies suggest that the utilisation of orders and other documentation can represent custom and practice within a relationship. Implied contract law hinges on notions of 'custom and practice'. Such custom and practice could be written evidence, such as regular orders, and, indeed, does not even have to be written down.

Business trading can operate outside of the formal legal system in a positive way. Systems of "private law" can provide extra-legal relational trading norms and enforcement. Selfenforcement can include trust, an expectation of relationship continuity, rules of exchange, social norms, 'unwritten laws', repeat trading, and reputational effects.

The relationship was characterised by close interpersonal interaction between customer and supplier. This is a relational exchange in terms of the situational and process characteristics described by Macneil. Indeed, a partnership, based on co-operation, with adaptations and resource dependence, and linked activities and resources, is entirely normal from an IMP perspective. Mutuality between actors is "...manifested in a common language regarding technical matters, contracting rules, and standardisation of process, products, and routines" (Hakansson and Johanson (1987:39)).

\section{5. / Conclusions}

The empirical case provides an interesting example of two opposing views of the possibility for legal redress following the dissolution of a long-term business relationship were there was no legal contract in place. The paper has combined three perspectives from the literature in assessing the views of the actors when one attempts to gain legal redress through the enforcement of a long-term relationship.

The Marks and Spencer-William Baird case is unusual for several reasons for the transaction cost economics, relational contracting, and industrial network literatures. First, there is no contract in place, however incomplete. Yet, here is an extreme example of dedicated assets, 
which should require heavy safeguards if not unilateral modes of governance. Plural form theory (Cannon, Achrol, and Gundlach (2000)) would expect relational norms in addition to an incomplete contract in the governance of business relationships. The use of contracts may not be prevalent in the sense that the enforcement of contracts through the courts should be considered as a last resort. Instead, actors are expected to co-operate based on the relational norms that Macneil discusses and have been empirically verified by others. In the M\&SWilliam Baird case an incomplete contract was non-existent. Further, the relational view would not expect actors to resort to redress for grievances through the formal legal system. Instead, we would expect within-relationship co-operation, or redress though systems of private law.

The industrial network literature takes a similar view that incomplete contracts are not important in the ongoing nature of business relationships. In other words, relationship development and maintenance over time is relational. However, this is an extreme case because a formal contract was non-existent. In addition, the degree of exclusivity between the customer and the supplier is extreme. Lastly, actors would not be expected to seek legal redress through the court system in managing their relationship (although there are a limited number of studies of relationship dissolution).

There are several special features of the case that make it unusual. This relationship was exceptional because the actors were reliant upon norms, custom and practice and written documents such as orders. Further, the supplier had only one customer, coupled with very specific asset investments. Perhaps relationships can be considered as akin to a formal contract between the parties. But there is clearly an issue with regard to the enforceability of a long-term relationship. 
Marks and Spencer Supply Net

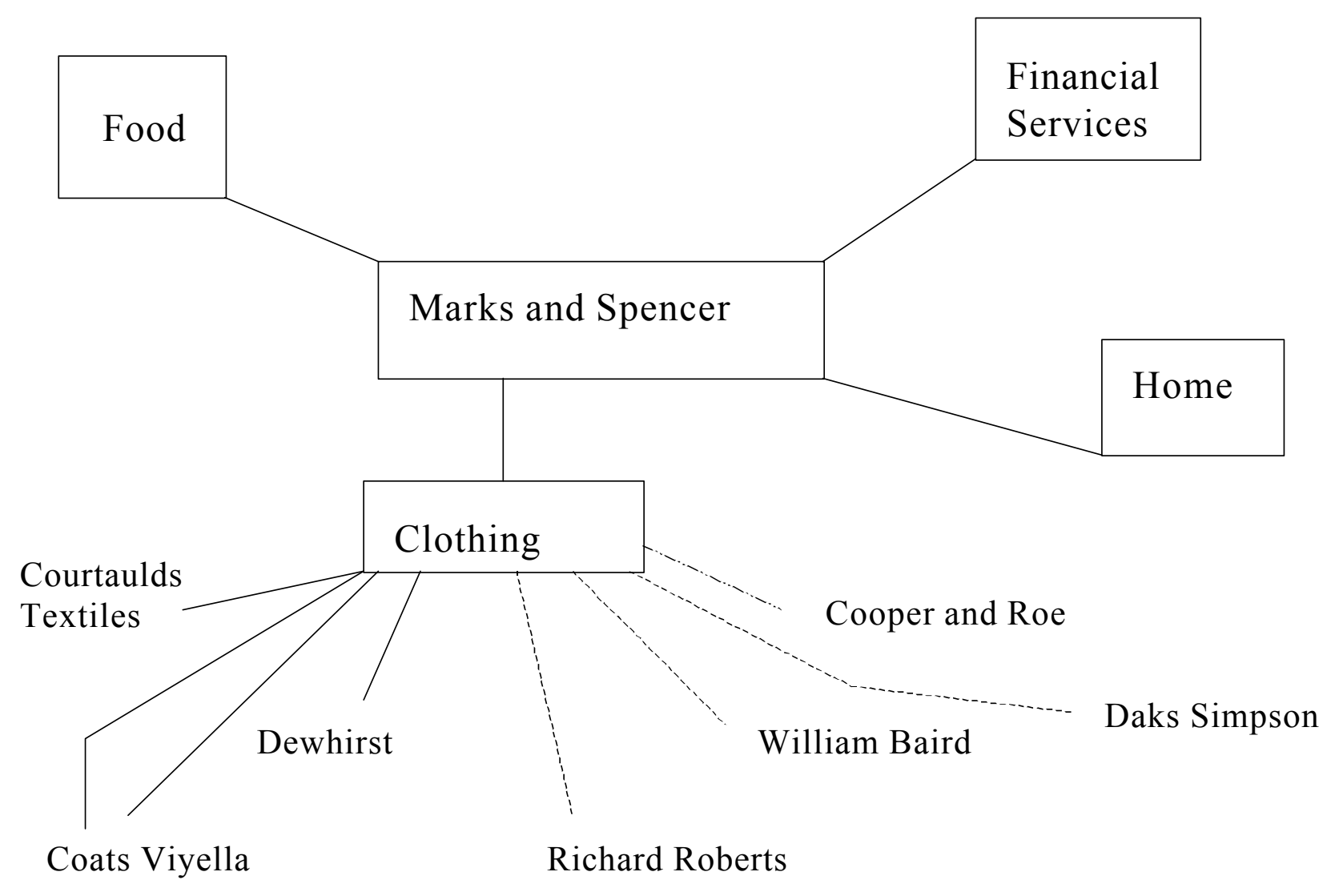




\section{Bibliography}

Anderson, E. and Weitz, B. (1989), Determinants of Continuity in Conventional Industrial Channel Dyads, Marketing Science, Vol. 8 (4): 310-324

Arrighetti, A., Bachmann, R., and Deakin, S. (1997), Contract law, social norms and interfirm co-operation, Cambridge Journal of Economics, Vol. 21(2): 171-195

Axelsson, B. (1992), Corporate strategy models and networks - diverging perspectives, In: Axelsson, B. and Easton, G. (eds.), Industrial Networks - A New View of Reality, 184-204, London: Routledge.

Bernstein, L. (1992), Opting Out Of the Legal-System - Extralegal Contractual Relations in the Diamond Industry, Journal of Legal Studies, Vol 21 (1): 115-157

Boyle, B., Dwyer, R., Robicheaux, R. A., and Simpson, J. T. (1992), Influence Strategies in Marketing Channels: Measures and Use in Different Relationship Structures, Journal of Marketing Research, Vol. 29: 462-473

Buckley, P. J. and Chapman, M. (1997), The perception and measurement of transaction costs, Cambridge Journal of Economics, Vol. 21: 127-145

Burchell, B. and Wilkinson, F. (1997), Trust, business relationships and the contractual environment, Cambridge Journal of Economics, Vol. 21(2): 217-237

Cannon, J.P., Achrol, R. S., and Gundlach, G. T. (2000), Contracts, Norms, and Plural Form Governance, Journal of the Academy of Marketing Science, Vol. 28(2): 180-194

Charny, D. (1996), Illusions of a Spontaneous Order: "Norms" in Contractual Relationships, University of Pennsylvania Law Review, Vol 144 (5): 1841-1857

Choi, C. J. (1994), Contract Enforcement across Cultures, Organisation Studies, Vol. 15(5): 673-682

Das, T. K. and Teng, B-S (1998), Between Trust and Control: Developing Confidence in Partner Co-operation in Alliances, Academy of Management Review, Vol. 23(3): 491-512

Deakin, S., Lane, C. and Wilkinson, F. (1994), 'Trust' or Law? Towards an Integrated Theory of Contractual Relations between Firms, Journal of Law and Society, Vol. 21(3): 329349

Dwyer, F. R., Schurr, P. H., and Oh, S. (1987), Developing Buyer-Seller Relationships, Journal of Marketing, Vol. 51: 11-27

Easton, G. and Araujo, L. (1989), The Network Approach: An Articulation, Advances in International Marketing, Vol. 3: 97-119.

Easton, G. and Lundgren, A. (1992), Changes in Industrial Networks as Flow Through Nodes, Axelsson, B. and Easton, G. (eds), Industrial Networks - A New View of Reality, 89104, London: Routledge. 
Ellickson, R. C. (1991), Order Without Law: How Neighbours Settle Disputes, Cambridge, Mass., Harvard University Press

Grabher, G. (1993), Rediscovering the social in the economics of interfirm relations, In Grabher, G. (ed.), The Embedded Firm, 1-31, London, Routledge

Griesinger, D. W. (1990), The Human Side of Economic Organisation, Academy of Management Review, Vol. 15(3): 478-499

Gundlach, G. T. and Achrol, R. S. (1993), Governance In Exchange - Contract Law and Its Alternatives, Journal of Public Policy and Marketing, Vol. 12 (2): 141-155

Hakansson, H. (1989), Corporate Technological Behaviour: Co-operation and networks, London: Routledge

Hakansson, H. (1992), Evolution Processes in industrial networks, In: Axelsson, B. and Easton, G., Industrial Networks: A New View of Reality, 129-143, London: Routledge.

Hakansson, H. and Henders, B., (1992), International Co-operative Relationships in Technological Development, In: Forsgren, M. and Johanson, J. (eds.), Managing Networks in International Business, 32-45, Philadelphia: Gordon and Breach.

Hakansson, H. and Johanson, J. (1988), Formal and Informal Cooperation Strategies in International Industrial Networks, In: Contractor, F. and Lorange, P. (eds.), Cooperative Strategies in International Business, 369-379, Lexington, MA: Lexington Books.

Hakansson, H. and Johanson, J. (1993), A Model of Industrial Networks, In: Axelsson, B. and Easton, G., Industrial Networks: A New View of Reality, 28-34, London: Routledge.

Hakansson, H. and Johanson, J. (1993), The network as a governance structure - Interfirm co-operation beyond markets and hierarchies, In Grabher, G. (ed.), The Embedded Firm, 3551, London, Routledge

Hakansson, H. and Snehota, I. (1989), No Business is an Island: The Network Concept of Business Strategy, Scandinavian Journal of Management, 5(3): 187-200.

Hakansson, H. and Snehota, I. (eds.) (1995), Developing Relationships in Business Networks, London: Routledge.

Havila and Salmi (1999), Spread of Change in Business Networks: An Empirical Study of Mergers and Acquisitions in the Graphic Industry, in McLoughlin, D. and C. Horan, (eds.), Proceedings of the $15^{\text {th }}$ Annual IMP Conference, University College, Dublin.

Heide, J.B. and John, G. (1992), Do Norms Matter in Marketing Relationships? Journal of Marketing, Vol. 56(2): 32-47

Joskow, P. L. (1987), Contract duration and transaction specific investment: empirical evidence from the coal markets, American Economic Review, Vol. 77 (1): 168-186 
Joskow, P. L. (1990), The Performance of Long-Term Contracts: Further Evidence from Coal Markets, The Rand Journal of Economics, Vol. 21 (2): 251-275

Leffler, K. B. and Rucker, R. R. (1991), Transactions Costs and the Efficient Organisation of Production: A Study of Timber-Harvesting Contracts, The Journal of Political Economy, Vol. 99 (5): 1060-1086

Kali, R. (1999), Endogenous Business Networks, The Journal of Law, Economics, and Organisation, Vol. 15(3): 615-636

Kumar, N., Scheer, L. K., and Steenkamp, J-B. E. M. (1995), The Effects of Supplier Fairness on Vulnerable Resellers, Journal of Marketing Research, Vol. 32: 54-65

Landa, J. T. (1994), Trust, Ethnicity, and Identity: Beyond the New Institutional Economics of Ethnic Trading Networks, Contract Law and Gift Exchange, Ann Arbor, Michigan University Press.

Lorenz, E. (1999), Trust, contract, and economic co-operation, Cambridge Journal of Economics, Vol. 23 (3): 301-315

Lundvall, B-A. (1993), Explaining interfirm co-operation and innovation: Limits of the transaction-cost approach, In: Grabher, G. (ed.), The embedded firm - on the socio-economics of industrial networks, 52-64, London: Routledge.

Lyons, B. and Mehta, J. (1997), Contracts, opportunism and trust: self-interest and social orientation, Cambridge Journal of Economics, Vol. 21(2): 239-257

Macneil, I. R. (1980), The new social contract: an inquiry into modern contractual relations, New Haven: Yale University Press

Macaulay, S. (1963), Non-Contractual Relations in Business, American Sociological Review, Vol. 28: 57-66

Maher, M. E. (1997), Transaction cost economics and contractual relations, Cambridge Journal of Economics, Vol. 21: 147-170

Murphy, M. (1999), Long-term Buyer/Supplier Governance Mechanisms: The Implications for Transaction Cost Theory - A Qualitative Study, In: McLoughlin, D. and C. Horan, (eds.), Proceedings of the $15^{\text {th }}$ Annual IMP Conference, University College, Dublin.

Noorderhaven, N. G. (1995), Transaction, Interaction, Institutionalisation: Toward a Dynamic Theory of Hybrid Governance, Scandinavian Journal of Management, Vol. 11 (1): 43-55

Paulin, M., Perrien, J., and Ferguson, R. (1997), Relational contract norms and the effectiveness of commercial banking relationships, International Journal of Service Industry Management, Vol. 8(5): 435-455

Rindfleisch, A. and Heide, J.B. (1997), Transaction Cost Analysis: Past, present, and future applications, Journal of Marketing, Vol. 61(4): 30-54 
Tahtinen, J. (1998), The Death of a Dyad: Theoretical Framework with an Empirical Illustration, In: Halinen-Kaila, A. and N. Nummela, (eds.), Proceedings of the $14^{\text {th }}$ Annual IMP Conference, Turku School of Economics and Business Administration, Turku.

Uusitalo, O., and Malinen, P. (1999), Impacts of the Changes in Purchasing and Subcontracting Policy on the Buyer-seller Relationship - The Case of Wartsila Marine's Bankruptcy, In: McLoughlin, D. and C. Horan, (eds.), Proceedings of the $15^{\text {th }}$ Annual IMP Conference, University College, Dublin.

Williamson, O. E. (1979), Transaction Cost Economics: The governance of Contractual Relations, The Journal of Law and Economics, Vol. 22: 233-261

Williamson, O. E. (1983), Credible Commitments: Using hostages to support exchange, American Economic Review, Vol. 36: 519-540

Williamson, O. E. (1991a), Comparative economic organisation: The Analysis of Discrete Structural Alternatives, Administrative Science Quarterly, Vol 36: 269-296 